\title{
Effect of the Plastic Cover on the Productivity and Profitability of Vineyard in the São Francisco River Valley, Brazil
}

\author{
Pedro V. de Azevedo ${ }^{1}$, Carlos A.C. dos Santos ${ }^{2,6}$ (D), Paulo C. da S. Lima ${ }^{3}$, \\ Mário de M.V.B. Ramos Leitão ${ }^{3}$, Gertrudes M. de Oliveira ${ }^{4}$, Raphael Abrahão ${ }^{5}$ \\ ${ }^{1}$ Instituto Federal de Educação, Ciência e Tecnologia do Rio Grande do Norte, Natal, RN, Brazil. \\ ${ }^{2}$ Unidade Acadêmica de Ciências Atmosféricas, Universidade Federal de Campina Grande, \\ Campina Grande, PB, Brazil. \\ ${ }^{3}$ Universidade Federal do Vale do São Francisco, Petrolina, PE, Brazil. \\ ${ }^{4}$ Universidade do Estado da Bahia, Juazeiro, BA, Brazil. \\ ${ }^{5}$ Universidade Federal da Paraíba, João Pessoa, PB, Brazil. \\ ${ }^{6}$ Daugherty Water for Food Global Institute, University of Nebraska-Lincoln, Lincoln, NE, USA.
}

Received: 21 May 2019 - Accepted: 1 September 2019

\begin{abstract}
Data from field experiments conducted in vineyards table grape variety of Festival in Petrolina-PE, from October/2009 to November/2010, were used to evaluate the influence of the plastic cover on productivity and economic profitability of the viticulture in the São Francisco River Valley. Three treatments were studied: uncovered canopy (UC), plastic cover placed at $50 \mathrm{~cm}$ above the canopy (PC50), and a plastic cover placed at $100 \mathrm{~cm}$ above the canopy (PC100). The results indicated that the increased supply of radiative fluxes at the height of the berries in the treatment PC100 contributed to higher productivity, while treatment PC50 had the lowest offer of irradiative fluxes at the height of berries and much lower productivity. The yield obtained in the treatment PC100 exceeded $11 \mathrm{t} \mathrm{ha}^{-1}$ and $12.3 \mathrm{tha}^{-1}$ to those of treatments at UC and PC50, respectively. Treatment PC100 also had the lowest amounts of defects of berries, which contributed to higher total revenue. By contrast, treatment PC50 had markedly lower productivity, which represented considerable economic losses.
\end{abstract}

Keywords: Vitis vinifera L, variety Festival, table grape, physical and commercial productivity, benefit/cost ratio.

\section{Efeito da Cobertura Plástica na Produtividade e Rentabilidade de Parreirais na Região do Vale do São Francisco}

\begin{abstract}
Resumo
Dados de experimentos de campo conduzidos em parreirais de uva de mesa da variedade Festival, em Petrolina-PE, no período de outubro/2009 a novembro/2010, foram usados para avaliar a influência da cobertura plástica sobre o microclima, produtividade e impacto econômico de parreirais. Foram estudados três tratamentos: sem cobertura (SC); com cobertura plástica posicionada a $50 \mathrm{~cm}$ acima do dossel (CP50); e com cobertura plástica posicionada a $100 \mathrm{~cm}$ acima do dossel (CP100). Os resultados indicaram que a maior oferta de fluxos radiativos na altura das bagas no tratamento CP100 contribuiu para uma maior produtividade, enquanto que o tratamento CP50 teve a menor oferta de fluxos radiativos na altura das bagas e uma produtividade bem menor. A produtividade obtida no tratamento CP100 superou em $11 \mathrm{t} \mathrm{ha}^{-1}$ àquela do tratamento $\mathrm{SC}$ e em 12,3 $\mathrm{tha}^{-1}$ a do tratamento CP50. O tratamento $\mathrm{CP} 100$, também foi o que apresentou as menores quantidades de defeitos graves e leves, o que contribuiu para uma maior receita total. Em contra partida, o tratamento CP50 teve uma produtividade acentuadamente menor, o que representou prejuízos econômicos consideráveis.
\end{abstract}

Palavras-chave: Vitis vinifera L, variedade Festival, uva de mesa, produtividade física e comercial, relação benefício/ custo.

Autor de correspondência: Carlos A. C. dos Santos, carlos.santos@ufcg.edu.br. 


\section{Introduction}

Grape is one of the fruits that have been most prominent in the semiarid region of São Francisco River Valley (SFRV), Northeast of Brazil (NEB), with increasing export volume (Hirsch, 2005). It is highly demanded by European countries and the United States, motivating exporters to invest in the expansion of cultivated areas and employment of technology, crop management, and packaging. Since the prices obtained in the foreign market are superior to those of the domestic market, guaranteeing higher economic profitability to the activity. Thus, the requirements of the producers, the new conditions, and the prospecting of new demands have been successfully adapted to the market in which they operate (Vitti et al., 2008).

The support of Brazil's insertion in the international market of table grapes is exclusively attributed to the increase of its cultivation, following technological standards of high technical and economic efficiency from the production phase to the processing and marketing. These procedures make the quality of the grape compatible, cost of production, and sales price at levels satisfactory to the maintenance of the competitiveness of the activity (Araujo and Correia, 2006). The table grape growth also plays an important social role in the region (SFRV) and generates labor occupation in the ratio of 5 men $\mathrm{day}^{-1} \mathrm{ha}^{-1}$ (Azevedo et al., 2012). It is composed mostly of women given the specificities of management operations in the field phase and the improvement of products that require specific manual skills and high concentration.

The semi-arid climate of the SFRV guarantees a high competitive differential to the other grape-producing regions of Brazil since it presents stable conditions throughout the year and allows the harvesting of up to three annual crops, whereas irrigation is used (Hirsch, 2005). In the region, the production system is planned to harvest during the periods from April to June and from October to December, when major market windows occur in importing countries, mainly in Europe and the United States (Vitti et al., 2008).

The protected cultivation of the grape, like other crops, is used worldwide, mainly in European countries of the Mediterranean region (Rana et al., 2004; Leitão et al., 2017). In general, the plastic cover is used for improving the thermo-hygrometric conditions when the atmospheric conditions are unfavorable to the plant growth and development, mostly adverse weather parameters, such as radiation, temperature, wind, and precipitation (Olmstead et al., 2001; Silva et al., 2011b). In Brazil, the plastic cover of vineyards was introduced to the State of Rio Grande do Sul, which has a cold climate with rainfall, strong winds, and hail at the time of grape maturation. These conditions can cause cracks and diseases (Santos et al., 2004; Chavarria et al., 2007, 2009; Leitão et al., 2017). The plastic cover has also been employed in other
States, such as the State of Paraná (Genta et al., 2010) and the State of São Paulo (Lulu et al., 2005; Pedro Jr. et al., 2007; Colombo et al., 2011).

Since 2004, the use of plastic covering arose from the need to use a protective mechanism against the installation of fungal diseases, which began to occur in the vineyards of the São Francisco Valley region. However, the phenomenon of splitting of some varieties of grape berries before or during harvesting has occurred in specific locations, associated to the occurrence of intense rainfall, high temperatures and low incidence of solar radiation (Palma et al., 1999; Vieira et al., 2008). According to Silva et al. (2011) and Leitão et al. (2017), the plastic cover provides a significant increase in air temperature on the canopy and acts as a physical barrier to the air movement.

Therefore, due to the strategic economic and social importance of the vineyards for the region, the plastic cover has been considered and recognized in studies on sustainability and competitiveness of table grape growth as an essential mechanism that must be improved. Thus, this study aimed to study the influence of the plastic cover on productivity and economic profitability of vineyard in the SFRV region, assessing the effects of the height of the plastic cover on the microclimate and productivity of vineyards and the loss caused by defects in the berries.

\section{Material and Methods}

\subsection{Experimental area}

The research was conducted in a vineyard of the table grape variety superior seedless, seedless Festival or simply Festival on the Águia do Vale Farm (9 6'14" S, $40^{\circ} 29^{\prime} 52^{\prime \prime} \mathrm{W} ; 360 \mathrm{~m}$ ), located in the Irrigation Project "Maria Teresa", Petrolina City - Pernambuco State throughout the phenological phases of maturation and harvesting for the period from September 19 to October 12, 2010. The vineyards were conducted in the trellis system and planting on $0.5 \mathrm{~m}$ height ridges and planting spacing of $3.5 \times 2.0 \mathrm{~m}$, as described in Leitão et al. (2017). It was used a plastic cover of low-density polyethylene (LDPE) film, $160 \mathrm{~mm}$ thick, transparent and $3 \mathrm{~m}$ wide. The irrigation system used in the vineyard was drip irrigation, with the application of weekly irrigation depth obtained to the flow of the irrigation system $\left(2.67 \mathrm{~mm} \mathrm{~h}^{-1}\right)$, based on crop coefficient $(K c=0.8)$ and reference evapotranspiration $\left(E T_{0}\right.$, in $\left.\mathrm{mm}\right)$ obtained from the weather station in Timbaúba Farm, located $13 \mathrm{~km}$ away from the experimental area, and the local rainfall $\left(R=777.2 \mathrm{~mm}_{\text {year }}{ }^{-1}\right)$.

Each plot consisted of three rows of plants, two of them covered with the same clear plastic used by producers in the region, willing and fixed on the canopy trellis in chapel format. The period of vineyard coverage occurred during the stages of maturation and grape harvest, as is 
traditionally done by local farmers. Field experiments were conducted in three treatments: uncovered canopy (UC), a plastic cover positioned at $50 \mathrm{~cm}$ above the canopy (PC50), and a plastic cover placed at $100 \mathrm{~cm}$ above the canopy (PC100). The early harvest was determined following the schedule established by the management of property that took as parameters the market demand and the minimum level of concentration in the berries soluble solids content (Brix $\geq 14 \%$ ). It was reviewed regularly during cultivation both in the laboratory of producer's cooperative as in own vineyard with a digital refractometer (ATAGO, model PAL-1 Digital Pocket Refractometer, USA).

The climatic conditions were monitored through the following instruments: air temperature sensors (HMP45, Campbell Scientific, Logan-UT, USA), psychrometers (Vaisala, Helsinki, Finland), anemometers (R. M. Young, Traverse, Michigan, USA), net radiometers (CNR1, Kipp \& Zonen, Logan-UT, USA), photosynthetically active radiation (PAR), Eppley Precision Spectral Pyranometer (PSP) (Eppley, Newport, RI, USA), equipped with solar filters (Eppley, Newport, RI, USA) and pluviometer (Tipping Bucket Rain Gauges, Texas Electronics, Dallas-TX, USA). All these sensors were connected to automatic data acquisition systems (CR23X and CR1000, Campbell Scientific, Logan-UT, USA), programmed to perform readings every 2 seconds, generate hourly and daily averages and daily extreme values (Azevedo et al., 2012; Leitão et al., 2017).

\subsection{Methodology}

The net radiation $(R n)$ is given by the sum of the shortwave and longwave radiation balances, based on the Eq. (1) (Leitão et al., 2017):

$$
R n=(K \downarrow-K \uparrow)+(L \downarrow-L \uparrow)
$$

where $K \downarrow$ is incident shortwave radiation; $K \uparrow$ is the reflected shortwave radiation; $L \downarrow$ is the long-wave radiation that arrives on the canopy emitted by the plastic cover and/or atmosphere, and $L \uparrow$ is the longwave radiation emitted by the canopy surface. All components of the radiation balance were measured with the CNR1.

Productivity $(P)$ was obtained, taking as a reference an estimated population of plants by $1 \mathrm{ha}$, as follows:

$$
P=n_{p} \cdot P_{p}
$$

where $n_{p}$ is the number of plants per hectare, and $P_{p}$ is the physical productivity obtained as the weight of bunches and loose berries of each plant.

Statistical analysis of productivity data for each treatment was performed using the SAS (Statistical Analysis System) software, from the determination of the standard deviation about the arithmetic mean of the obtained values. This measure provides an estimate of the degree of precision of the estimated average data. Thus, the average standard error was used as the measure for comparison of treatment, given by:

$$
s=\sqrt{\frac{S S D}{N-i}}
$$

where $s$ is the standard deviation, SSD the sum of squares of differences and $N$ the number of observations.

Financial income $\left(F_{i}\right)$ was determined considering two different marketing scenarios:

Scenario 1: When the beneficiation operations fully complied with the technical regulation of identity and grape quality, regarding the elimination of severe and minor defects, as recommended by the Normative Instruction $n^{\circ} 1$ of February $1^{\text {st }}, 2002$ (Brazil, 2002);

Scenario 2: When the bunches with defects (immature grapes rot on stems and profound damage) were taken to be marketed in a transparent plastic bag of $500 \mathrm{~g}$ called "begging bowl" very commercialized in the European market.

This form of market production, unlike packages of $5 \mathrm{~kg}$ boxes, enables even bunches defects can be partially recovered by removing the portion with the imperfection of the bunches to minimize losses caused by climate and phytosanitary variations that interfere with harnessing the productivity of vineyards:

$$
F_{i}=p \cdot q
$$

where $p\left(\mathrm{R} \mathrm{k} \mathrm{kg}^{-1}\right)$ is the average annual price and $q(\mathrm{~kg})$ the quantities of grapes marketed effectively.

The economic evaluation of the results was obtained, considering the calculation of total revenue based on physical production, which made it possible that the number of defective grapes was quantified monetarily and its corporate impact on the economic analysis. From comparisons of total revenue, total cost, and economic productivity, the following indexes of economic efficiency were obtained:

$$
\text { - Benefit/cost relation }\left(R_{B / C}\right) \text { : }
$$

$$
R_{B / C}=\frac{R_{t}}{C_{t}}
$$

where $R_{t}$ is the total revenue ( $\mathrm{R} \$$ ) and $C_{t}$ the total annual cost of the grape variety Festival (R\$) provided by the owner of the property that hosted the experiments, converted to cost per hectare. 
- Point leveling or balance $\left(P_{n}\right)$ :

$$
P_{n}=\frac{C_{t}}{P_{s}}
$$

where $P_{s}$ is the annual average value of the sale and the margin of safety $\left(M_{s}\right)$ given as:

$$
M_{s}=\frac{\left(C_{t}-R_{t}\right)}{R_{t}}
$$

\section{Results and Discussion}

The data presented in Table 1 indicate that, under the canopy, the lower values of radiative fluxes ( $R n$ and $P A R$ ) and productivity $(P)$ occurred in the PC50 treatment. This is associated with the climatic conditions generated by the plastic cover positioned at a shorter distance above the canopy, which contributed to the reduction of short-wave radiation, net radiation and particularly of photosynthetically active radiation (Amarante et al., 2007; Conceição and Marin, 2009; Mota et al., 2009; Cardoso et al.,

Table 1 - Average daily of net radiation $(R n)$, photosynthetically active radiation $(P A R)$, observed for the grapes variety Festival under the following treatments: uncovered canopy (UC); a plastic cover positioned at $50 \mathrm{~cm}$ above the canopy (PC50); and a plastic cover placed at $100 \mathrm{~cm}$ above the canopy (PC100) throughout maturation and harvest; leaf area index $(L A I)$ and productivity $(P)$.

\begin{tabular}{lcccc}
\hline Treatment & \multicolumn{4}{c}{ First experiment $(2009)$} \\
\cline { 2 - 5 } & $R n\left(\mathrm{~W} \mathrm{~m}^{-2}\right)$ & $P A R\left(\mathrm{~W} \mathrm{~m}^{-2}\right)$ & $L A I\left(\mathrm{~m}^{2} \mathrm{~m}^{-2}\right)$ & $P\left(\mathrm{t} \mathrm{ha}^{-1}\right)$ \\
\hline $\mathrm{UC}$ & 29.1 & 23.1 & 8.5 & 26.8 \\
PC50 & 23.7 & 18.8 & 6.6 & 9.8 \\
PC100 & 25.2 & 20.8 & 6.8 & 26.4 \\
\hline Treatment & & Second experiment $(2010)$ & \\
\cline { 2 - 5 } & $\left.R n(\mathrm{~W} \mathrm{~m})^{-2}\right)$ & PAR $\left.(\mathrm{W} \mathrm{m})^{-2}\right)$ & $L A I\left(\mathrm{~m}^{2} \mathrm{~m}^{-2}\right)$ & $\left.P(\mathrm{t} \mathrm{ha})^{-1}\right)$ \\
\hline UC & 60.1 & 35.1 & 6.6 & 19.1 \\
PC50 & 38.0 & 20.7 & 5.9 & 17.8 \\
PC100 & 109.2 & 58.9 & 3.8 & 30.1 \\
\hline
\end{tabular}

2010; Comiran et al., 2012; Leitão et al., 2017). As a result, there was a marked reduction in productivity. On the other hand, the higher values of radiative fluxes in 2009 took place in the UC treatment, which had the highest $P\left(26.8 \mathrm{t} \mathrm{ha}^{-1}\right)$, followed closely by PC100 treatment $\left(26.4 \mathrm{t} \mathrm{ha}^{-1}\right)$. However, in 2010, the values of radiative fluxes observed to PC100 treatment, and $P$ were much higher than in other treatments. The production obtained in PC100 treatment exceeded $11 \mathrm{t} \mathrm{ha}^{-1}$ that of UC treatment and $12.3 \mathrm{t} \mathrm{ha}^{-1}$ at the PC50 treatments. These results show that the increased supply of radiative fluxes in the PC100 treatment contributed to increasing $P$. This fact reinforces the idea that, in the region of the SFRV, the height of the plastic cover is critical to generating favorable microclimate conditions for the table grape vegetative growth and productivity. However, the PC50 is traditionally used in the region, contributing to a significant reduction in productivity and considerable economic damage to producers.

\subsection{Productivity analysis}

The average values of physical, marketable, and discarded productivities are shown in Table 2. The first experimental campaign (2009) revealed that the PC50 treatment had the lowest physical productivity $\left(9.8 \mathrm{t} \mathrm{ha}^{-1}\right)$ and commercial productivity $\left(9.4 \mathrm{tha}^{-1}\right)$, which is equivalent to about one-third of the productivity of the other procedures. The UC treatment showed higher physical productivity $\left(26.8 \mathrm{t} \mathrm{ha}^{-1}\right)$, the second most considerable commercial productivity $\left(24.2 \mathrm{t} \mathrm{ha}^{-1}\right)$ and the highest discarded productivity $\left(2.4 \mathrm{t} \mathrm{ha}^{-1}\right)$. These results indicate that the change in the microclimate caused by the height of the plastic cover above the canopy has generated variations in physical productivity and the occurrence of defects in bunches and berries, influencing the marketable product. In the second experimental campaign (2010), the highest grape physical productivity was found to the PC100 treatment $\left(30.9 \mathrm{t} \mathrm{ha}^{-1}\right)$, followed by UC (19.0 $\left.\mathrm{t} \mathrm{ha}^{-1}\right)$ and PC50 $\left(17.8 \mathrm{t} \mathrm{ha}^{-1}\right)$ treatments (Table 2$)$, respectively. However, when considering economic productivity (scenario 1) due

Table 2 - Physical and commercial productivity and discarded grapes from vineyards with uncovered canopy (UC); a plastic cover positioned at $50 \mathrm{~cm}$

\begin{tabular}{|c|c|c|c|c|c|c|c|c|}
\hline \multirow[t]{4}{*}{ Treatment } & \multicolumn{8}{|c|}{ Productivity $\left(\mathrm{t} \mathrm{ha}^{-1}\right)$} \\
\hline & \multicolumn{3}{|c|}{ First experiment (2009) } & \multicolumn{5}{|c|}{ Second experiment (2010) } \\
\hline & \multirow[t]{2}{*}{ Physical } & \multirow[t]{2}{*}{ Commercial } & \multirow[t]{2}{*}{ Discarded $(*)$} & \multirow[t]{2}{*}{ Physical } & \multicolumn{2}{|c|}{ Commercial } & \multicolumn{2}{|c|}{ Discarded (*) } \\
\hline & & & & & Scenario $1(*)$ & Scenario $2(* *)$ & Bunch & Bulk \\
\hline $\mathrm{UC}$ & 26.8 & 24.2 & 2.4 & 19.0 & 15.6 & 16.7 & 1.1 & 2.3 \\
\hline PC50 & 9.8 & 9.4 & 0.4 & 17.8 & 15.4 & 16.3 & 0.9 & 1.5 \\
\hline PC100 & 26.4 & 25.2 & 1.1 & 30.9 & 27.0 & 28.0 & 1.1 & 2.8 \\
\hline
\end{tabular}
above the canopy (PC50); and a plastic cover placed at $100 \mathrm{~cm}$ above the canopy (PC100) treatments, in the municipality of Petrolina-PE.

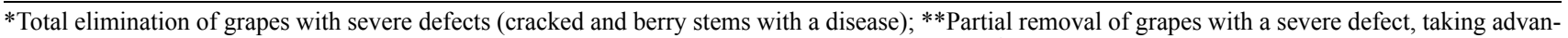
tage of the composition in $1 \mathrm{~kg}$ packs, not observing the Normative Instruction $\mathrm{n}^{\mathrm{o}} 1$ of February $1^{\text {st }}, 2002$ (Brazil, 2002). 
to a significant increase in bulk berries, the difference between it and the UC and PC50 treatments increases to $42.2 \%$ and $42.9 \%$, respectively.

The highest difference in discarded productivity was recorded in the form of bulk, while in bunches mode values were nearly identical. The PC100 treatment showed the most substantial amount (bunch + bulk) discarded productivity $\left(3.9 \mathrm{tha}^{-1}\right)$, followed by UC $\left(3.4 \mathrm{t} \mathrm{ha}^{-1}\right)$ and the PC50 (2.4 t ha ${ }^{-1}$ ) (Tables 2 and 3). The impact of these losses on commercial productivity was higher in scenario 1 conditions. Thus, the average physical productivity of PC100 treatment $\left(30.9 \mathrm{t} \mathrm{ha}^{-1}\right)$ was statistically more significant than that from the other treatments (UC and PC50), which were not statistically different from each other. This result makes it possible to infer that in the PC100 treatment, the height of the plastic cover above canopy positively influenced the physical productivity, and significantly increased the production, compared to UC and PC50 treatments. It should be mentioned that in both scenarios, the average values of commercial products are the most critical focus of the assessments, and they represent the commercial terms grape compatible with Normative Instruction $\mathrm{n}^{\circ} 1$ of February $1^{\text {st }}, 2002$ (Brazil, 2002). The performances regarding the productivity of the treatments covered in the two experimental campaigns indicate that the PC100 treatment had much higher productivity than the PC50 treatment. Therefore, the height of the plastic cover on the vineyard canopy influenced both in physical productivity as ruled in quantity as well as directly to the economic production.

\subsection{Economic profitability}

The evaluation of the economic cost-effectiveness of Festival grape cultivation for both experimental campaigns is shown in Tables 3 and 4 . Revenue amounts are derived from the marketing of products as it occurs, where the owner is paid based on the average annual price of one kilogram of grape in the corresponding market (national or international). The physical production refers to the physiological production of the plant which, after having benefited from the elimination of severe and minor defects, is marketed in specific markets according to its standard: grapes without defects are exported or marketed in the national market in supermarket chains, and the local vinegar industry or peddlers purchase defective grapes.

The average annual price of $1 \mathrm{~kg}$ of grapes in the domestic or international market of $\mathrm{R} \$ 4.00$ and the grapes sold under vineyards industrial and local fairground $\mathrm{R} \$$ 0.30. Prices reported by the Agricultural Cooperative of Juazeiro-BA - ACJ.

It is observed in Table 3 that in the first experimental campaign (2009), the highest total revenue (R\$ 101,344.00) was generated by PC100 treatment and the lowest (R\$ 37,656.00) for the PC50 treatment. The UC treatment, although it had a slightly higher physical productivity $\left(26.8 \mathrm{t} \mathrm{ha}^{-1}\right)$ against $\left(26.4 \mathrm{tha}^{-1}\right)$ in the PC100, and had a total revenue (R\$ 97,670.00) which is $3.6 \%$ lower. It has resulted in the difference between the volumes marketed in the vinegar industry and peddlers $\left(2.4 \mathrm{tha}^{-1}\right)$ to $\left(1.1 \mathrm{t} \mathrm{ha}^{-1}\right)$ in the UC and PC100 treatment (Table 3), respectively. In the second experimental campaign (2010), for the marketing scenario 1, the highest revenue collected (R\$100,967.00) was also obtained in PC100 treatment. The UC and PC50 treatments showed smaller and slightly revenue differences from each other $\mathrm{R}$ $\$ 58,596.00$ and $\mathrm{R} \$ 57,628.00$, respectively. It is also observed that most revenues for the PC100 treatment resulted significantly from its higher physical productivity $\left(30.9 \mathrm{tha}^{-1}\right)$ against UC (18.9 $\left.\mathrm{tha}^{-1}\right)$ and PC50 (17.8 $\left.\mathrm{tha}^{-1}\right)$ treatments (Tables 3 and 4), respectively. Proportionally, there was also a smaller number of defects in the PC100

Table 3 - Physical productivity $\left(P_{p}\right)$, commercial productivity $\left(P_{c}\right)$ for internal/external markets $\left(M_{i / e}\right)$ and industry/peddlers $\left(M_{i / p}\right)$ and total revenue $\left(R_{t}\right)$ grape variety Festival estimated by hectare for uncovered treatment (UC) and covered with plastic (PC50) and (PC100), harvested in the falls of 2009 and 2010, in Petrolina-PE.

\begin{tabular}{|c|c|c|c|c|c|c|}
\hline \multirow[t]{3}{*}{ Treatment } & \multicolumn{6}{|c|}{ First experiment (2009) } \\
\hline & \multirow[t]{2}{*}{$P_{p}\left(\mathrm{tha}^{-1}\right)$} & \multicolumn{2}{|c|}{$P_{c}\left(\mathrm{tha}^{-1}\right)$} & \multicolumn{2}{|c|}{$R_{t}(\mathrm{R} \$ 1,00)$} & \multirow[b]{2}{*}{ Total } \\
\hline & & $M_{i / e}$ & $M_{i / p}$ & $M_{i / e}$ & $M_{i / p}$ & \\
\hline $\mathrm{UC}$ & 26.8 & 24.2 & 2.4 & 96.936 & 734 & 97.670 \\
\hline PC50 & 9.8 & 9.4 & 0.4 & 37.541 & 115 & 37.656 \\
\hline PC100 & 26.4 & 25.3 & 1.1 & 101.003 & 340 & 101.344 \\
\hline \multirow[t]{3}{*}{ Treatment } & \multicolumn{6}{|c|}{ Second experiment (2010) } \\
\hline & \multirow[t]{2}{*}{$P_{p}\left(\mathrm{tha}^{-1}\right)$} & \multicolumn{2}{|c|}{$P_{c}\left(\mathrm{t} \mathrm{ha}^{-1}\right)$} & \multicolumn{2}{|c|}{$R_{t}(\mathrm{R} \$ 1,00)$} & \\
\hline & & $M_{i / e}$ & $M_{i / p}$ & $M_{i / e}$ & $M_{i / p}$ & Total \\
\hline $\mathrm{UC}$ & 18.9 & 15.6 & 3.4 & 57.573 & 1.023 & 58.596 \\
\hline PC50 & 17.8 & 15.4 & 2.4 & 56.894 & 734 & 57.628 \\
\hline PC100 & 30.9 & 27.0 & 3.9 & 99.797 & 1.169 & 100.967 \\
\hline
\end{tabular}


Table 4 - Economic evaluation of the grape variety Festival, based on physical productivity $\left(P_{p}\right)$, economic productivity $\left(P_{e}\right)$, total cost $\left(C_{t}\right)$, benefit/cost ratio $\left(R_{b / c}\right)$, leveling point $\left(P_{n}\right)$ and margin of safety $\left(M_{s}\right)$.

\begin{tabular}{|c|c|c|c|c|c|c|}
\hline \multirow[t]{2}{*}{ Treatment } & \multicolumn{6}{|c|}{ First experiment (2009) } \\
\hline & $P_{p}\left(\mathrm{t} \mathrm{ha}^{-1}\right.$ year $\left.^{-1}\right)$ & $P_{e}(\mathrm{R} \$ 1.00)$ & $C_{t}(\mathrm{R} \$ 1.00)$ & $R_{b / c}$ & $P_{n}\left(\mathrm{t} \mathrm{ha}^{-1}\right.$ year $\left.^{-1}\right)$ & $M_{s}$ \\
\hline $\mathrm{UC}$ & 26.8 & 97.670 & & 2.44 & & -0.55 \\
\hline PC50 & 9.8 & 37.656 & 43.800 & 0.89 & 10.9 & 0.16 \\
\hline PC100 & 26.4 & 101.344 & & 2.41 & & -0.57 \\
\hline \multirow[t]{2}{*}{ Treatment } & \multicolumn{6}{|c|}{ Second experiment (2010) } \\
\hline & $P_{p}\left(\mathrm{tha}^{-1}\right.$ year $\left.^{-1}\right)$ & $P_{e}(\mathrm{R} \$ 1.00)$ & $C_{t}(\mathrm{R} \$ 1.00)$ & $R_{b / c}$ & $P_{n}\left(\mathrm{tha}^{-1}\right.$ year $\left.^{-1}\right)$ & $M_{s}$ \\
\hline $\mathrm{UC}$ & 18.9 & 58,596 & & 1.41 & & -0.26 \\
\hline PC50 & 17.8 & 57,628 & 44,100 & 1.38 & 11.9 & -0.23 \\
\hline PC100 & 30.9 & 100,967 & & 2.37 & & -0.56 \\
\hline
\end{tabular}

treatment $(12.6 \%)$, while in PC50 and UC treatments were $13.7 \%$ and $21 \%$, respectively. In general, the PC100 treatment, as compared to the other treatments, contributed to the increase in productivity and defects reduction. The PC100 treatment generated favorable microclimate conditions (Leitão et al., 2017) to increase productivity, which provided that this treatment had the highest total revenue for all treatments.

The productivity values, revenues, costs and economic indices presented in Table 4 indicate that the change in rates (benefit/cost and safety margin) reflects productivity differences resulting from the different treatments. They are analyzed separately considering the economic income rather than revenue based on physical productivity. For the first experimental campaign (2009), the benefit/cost was proportional to productivity, with the highest value (2.44) obtained on UC treatment. This means that for every $\mathrm{R} \$ 1.00$ invested in the total cost of this treatment, there was a return of $\mathrm{R} \$ 2.44$. For the $\mathrm{PC} 100$ treatment, the benefit/cost was very close $(\mathrm{R} \$$ 2.41); and, for the PC50 treatment was significantly reduced by $\mathrm{R} \$ 0.89$. As a result, the margin of safety for the PC50 treatment showed the worst index (0.16) (Table 4), indicating that the coverage positioned $50 \mathrm{~cm}$ above canopy height had economic productivity below the leveling point. Thus, the PC50 treatment was economically deficient, i.e., so that it equaled the revenues to costs; the sale price of grape kilograms should be $216 \%$ higher than the average market price practiced at the time (2009). The highest safety margins were cleared in UC treatment $(-0.57)$ and PC100 (-0.55), an adjustable safety belt concerning fluctuations in the price of grape practiced by the market kilogram. Therefore, any price drop in the grape kilogram that does not exceed $57 \%$ and $55 \%$, respectively, still maintain the economic viability of PC100 and UC treatments. Therefore, the results of this first experimental campaign indicate that the PC50 treatment presented itself as an uneconomic cultivation alternative, while the UC and the PC100 treatments have proved to be economically viable.
For the second experimental campaign (2010), the indexes "benefit/cost" and "margin of safety" were analyzed separately (Table 4) and reflect productivity differences resulting from the treatment discovered and covered with plastic sheeting. In this case, the total revenue was calculated based on economic revenues not considering $100 \%$ of real productivity and based on a single average selling price, a factor that must be considered when assessing interpretation to economic results. Thus, the benefit/ cost varied in proportion to productivity, the most significant amount determined in the PC100 treatment. Therefore, for the PC100 treatment, for every R\$ 1.00 invested was calculated a return of $\mathrm{R} \$ 2.37$, which is $43.2 \%$ higher than the average calculated for the UC and PC50 treatments. For safety margin values were determined PC100 $=-0.56, \mathrm{UC}=-0.26$, and PC50 $=-0.23$, indicating that even with a reduction of up to $56 \%$ in the average grape price, the $\mathrm{PC} 100$ treatment would still have revenue equal to the costs. For the other two treatments, the margin on average would drop to $24 \%$. These results indicate that treatment with plastic sheeting positioned at $100 \mathrm{~cm}$ above canopy height was the only alternative economically viable of the three treatments studied. These results may be related to prevailing climatic conditions during the second cultivation period, which showed little cloudiness and higher temperatures (Leitão et al., 2017), causing more favorable conditions for the development of the plant in the PC100 treatment than that found in the PC50 treatment.

The indices shown in Table 5 indicate that in the second experiment (2010) for trading done in the "begging bowl", the PC100 treatment compared with the UC and PC50 treatments appeared to be an alternative economically very viable. Therefore, as discussed in the analyses carried out based on Table 4, the prevailing climatic conditions associated with marketing method, showed that the treatment PC100 was economically more profitable. Thus, considering the scenario 2 (Table 5), the total revenue for the PC100 treatment ( $\mathrm{R} \$ 104,557.98)$ was $41.1 \%$ exceeded the average income calculated for UC and PC50 treat- 
Table 5 - Total revenue from one hectare of grape variety Festival, based on scenario 2, for the discovered (UC), covered (PC50) and (PC100) treatments, calculated for the second experimental campaign in 2010, in Petrolina-PE.

\begin{tabular}{|c|c|c|c|c|c|c|}
\hline \multirow[t]{2}{*}{ Treatment } & \multirow[t]{2}{*}{$P_{p}\left(\mathrm{tha}^{-1}\right)$} & \multicolumn{2}{|c|}{$P_{c}\left(\mathrm{t} \mathrm{ha}^{-1}\right)$} & \multicolumn{2}{|c|}{$R_{t}(\mathrm{R} \$)$} & \multirow[b]{2}{*}{ Total } \\
\hline & & $M_{i / e}$ & $M_{i / p}$ & $M_{i / e}$ & $M_{i / p}$ & \\
\hline $\mathrm{UC}$ & 18.9 & 16.7 & 2.3 & $61,683.41$ & 689.78 & $62,373.19$ \\
\hline PC50 & 17.8 & 16.3 & 1.5 & $60,352.90$ & 453.66 & $60,806.56$ \\
\hline PC100 & 30.9 & 28.0 & 2.8 & $103,705.31$ & 852.67 & $104,557.98$ \\
\hline
\end{tabular}

ments $(\mathrm{R} \$ 61,589.88)$. These results show that the physical productivity of PC100 $\left(30.9 \mathrm{t} \mathrm{ha}^{-1}\right)$ was decisive in obtaining this increased revenue since the income established with sales to the vinegar industry and peddlers, which paid only R $\$ 0.30 /$ kilogram of grape, were practically insignificant.

\section{Conclusions}

The evaluation of the influence of the plastic cover on productivity and economic profitability of table viticulture in the São Francisco River Valley region shows that:

1. The plastic cover positioned at $100 \mathrm{~cm}$ above canopy (PC100) treatment provides a higher supply of radiative fluxes, higher physical productivity and fewer severe and mild defects in bunches and berries, creating a higher total revenue;

2. By contrast, the plastic cover positioned at $50 \mathrm{~cm}$ above canopy (PC50) treatment, a traditional practice adopted in the region, provides a lower supply of radiative fluxes, more significant amount of severe and minor defects in bunches and berries, resulting in sharply lower productivity, lower total revenue, and economic damage;

3. The benefit/cost ratio $\left(R_{B / C}\right)$ is directly affected by climatic conditions generated by the coverage position above the canopy, since the average benefit/cost of treatment $\mathrm{PC} 100\left(R_{B / C}=2.39\right)$ is more than twice that of PC50 treatment $\left(R_{B / C}=1.13\right)$ and about $20 \%$ over that of treatment without cover $\left(R_{B / C}=1.92\right)$. Therefore, concerning the margin of safety, the PC100 treatment performs better, and it is the most economically viable among treatments.

\section{Acknowledgments}

The authors thank the Federal University of São Francisco Valley (UNIVASF) for technical assistance and research, the Farm "Eagle Valley" by releasing the area for installation and conducting field experiments. The second author is thankful to the Coordination for the Improvement of Higher Education Personnel (CAPES) - Finance Code 001 (Visiting Professor Fellowship - Grant N ${ }^{\circ} .88881 .172029$ / 2018-01) and to the National Council for Scientific and
Technological Development (CNPq) for the Research Productivity Grant (Grant N. 304493/2019-8). The support of the Daugherty Water for Food Global Institute at the University of Nebraska is also appreciated.

\section{References}

Amarante, C.V.T.; Steffens, C.A.; Mota, C.S.; Santos, H.P. Radiação, fotossíntese, rendimento e qualidade de frutos em macieiras 'Royal Gala' cobertas com telas antigranizo. Pesquisa Agropecuária Brasileira, v. 42, n. 7, p. 925-931, 2007.

Araújo, J.L.P.; Correia, R.C. Análise do custo de produção e rentabilidade do cultivo da uva fina de mesa sem sementes produzida na região do Submédio São Francisco. In: XIII SIMPEP - Bauru. São Paulo, Brasil, 06 a 08 de novembro de 2006.

Azevedo, P.V.; Bezerra, J.R.C.; Silva, V.P.R. Evapotranspiration and water-use efficiency of irrigated colored cotton cultivar in semiarid regions. Agricultural Sciences, v. 3, n. 5, p. 714-722, 2012.

BRAZIL: Ministério da Agricultura, Pecuária e Abastecimento - MAPA. Instrução Normativa $n^{\circ} 1$, de $1^{\circ}$ de fevereiro de 2002. Regulamento técnico de identidade e de qualidade para a classificação da uva fina de mesa. Diário Oficial da República Federativa do Brasil, Brasília, 4 de fevereiro de 2002, Seção 1, 7 p.

Cardoso, L.S.; Bergamaschi, H.; Comiran, F.; Chavarria, G.; Marodin, G.A.B.; Dalmago, G.A.; Santos, H.P.; Mandelli, F. Padrões de interceptação de radiação solar em vinhedos com e sem cobertura plástica. Revista Brasileira de Fruticultura, v. 32, n. 1, p. 161-171, 2010.

Chavarria, G.; Santoa, H.P.; Mandelli F.; Marodin, G.A.B.; Bergamaschi, H.; Cardoso, L.S. Potencial produtivo de videiras cultivadas sob cobertura de plástico. Pesquisa Agropecuária Brasileira, v. 44, n. 2, p. 141-147, 2009.

Chavarria, G.; Santos, H.; Sônego, O.R.; Marodin, G.A.B.; Bergamaschi; H.; Cardoso, L.S. Incidência de doenças e necessidade de controle em cultivo protegido de videira. Revista Brasileira de Fruticultura, v. 29, n. 3, p. 477-482, 2007.

Colombo, L.A.; Assis, A.M.; Sato, A.J.; Tessmann, D.J.; Genta, W.; Roberto, S.R. Produção fora de época da videira 'BRS Clara' sob cultivo protegido. Ciência Rural, v. 41, n. 2, p. 212-218, 2011.

Comiran, F.; Bergamaschi, H.; Heckler, B.M.M.; Santos, H.P.; Alba, D.; Saretta, E. Microclima e produção de videiras 'Niágara Rosada' em cultivo orgânico sob cobertura plás- 
tica. Revista Brasileira de Fruticultura, v. 34, n. 1, p. 152-159, 2012.

Conceição, M.A.F.; Marin, F.R. Condições microclimáticas em um parreiral irrigado coberto com tela plástica. Revista Brasileira de Fruticultura, v. 31, n. 2, p. 423-431, 2009.

Genta, W.; Tessmann, D.J.; Roberto, S.R.; Vida, J.B.; Colombo, L.A.; Scapin, C.R.; Ricce, W.S.; Clovis, L.R. Manejo de míldio no cultivo protegido de videira de mesa 'BRS Clara'. Pesquisa Agropecuária Brasileira, v. 45, n. 12, p. 1388-1395, 2010.

Hirsch, R. São Francisco Valley Irrigated Fruit Production: An Interesting Alternative for New Investments. Rabobank International, 2005, $64 \mathrm{p}$.

INSTITUTO BRASILEIRO DE FRUTAS - IBRAF. Estatística: comparativo das exportações brasileiras de frutas frescas 2003-2008. frutas frescas/exportação. Disponível em: <http://www.ibraf.org.br/estatisticas/Exportação/Compara tivoExportacoesBrasileiras2008-2007.pdf>. Último acesso em: 11 maio 2011.

Leitão, M.M.V.B.R.; Azevedo, P.V.; Lima, P.C.S.; Oliveira, G.M.; Santos, C.A.C. Influence of plastic covering on the microclimate in vineyards in the São Francisco River Valley Region. Revista Brasileira de Meteorologia, v. 32, n. 3, p. 399-407, 2017.

Lulu, J.; Castro, J.V.; Pedro Júnior, M.J. Efeito do microclima Efeito do microclima na qualidade da uva de mesa 'romana' (A 1105) cultivada sob cobertura plástica. Revista Brasileira de Fruticultura, v. 27, n. 3, p. 422-425, 2005.

Mota, C.S.; Amarante, C.V.T.; Santos, H.P.; Albuquerque, J.A. Disponibilidade hídrica, radiação solar e fotossíntese em videiras 'Cabernet Sauvignon' sob cultivo protegido. Revista Brasileira de Fruticultura, v. 31, n. 2, p. 432-439, 2009.

Olmstead, M.A.; Wample, R.L.; Greene, S.L.; and Tarara, J.M. Evaluation of Potential Cover Crops for Inland Pacific Northwest Vineyards. American Journal of Enology and Viticulture, v. 52, n. 4, p. 292-303, 2001.

Palma, L.; Novello, V.; Tarricone, L. Changes of solar radiation and air $\mathrm{CO}_{2}$ concentration: effects on ecophysiolo- gical activity, vine growth and production in table grape grown under protected conditions. In: XI Meeting Study Group for Vine Training Systems. Marsala. Universitàde Gli Studi di Palermo, v. 2, p. 711-717, 1999.

Pedro Júnior, M.J.; Pezzopane, J.R.; Hernandes, J.L.; Lulu, J.; Castro, J.V. Avaliações microclimáticas e das características de qualidade da uva de mesa 'Romana' com proteção individual dos cachos. Bragantia, v. 66, n. 1, p. 165171, 2007.

Rana, G.; Kateriji, N.; Introna, M.; Hammami, A. Microclimate and plant water relationship of the "overhead" table grape vineyard managed with three different covering techniques. Scientia Horticulturae, v. 102, n. 1, p. 105-120, 2004.

Santos, A.O.; Pedro Júnior. J.; Ferreira, M.A.; Hernandez, J.L. Ecophysiology and yield performance of grape Cabernet sauvignon cultivated under different exposures. Acta Scientiarum. Agronomy, v. 26, n. 3, p. 263-271, 2004.

Silva, B.K.N.; Silva, V.P.R.; Azevedo, P.V.; Farias, C.H.A. Análise de sensibilidade dos métodos de estimativa da evapotranspiração de referência e razão de Bowen em cultura da cana-de-açúcar. Revista Brasileira de Engenharia Agrícola e Ambiental, v. 15, n. 10, p. 1046-1053, 2011 a.

Silva, P.C.L.; Ramos Leitão, M.M.V.B.; Azevedo, P.V. Influência da Cobertura Plástica Sobre a Temperatura em Parreirais no Vale do Submédio São Francisco. Revista Brasileira de Geografia Física, v. 4, n. 1, p. 45-56, 2011 b.

Vieira, H.J.; Silva, A.L.; Arcri, S.G.; Bruna, E.D.; Back, A.J.; Pandolfo, C. Rachaduras da uva Goethe em condições de alta umidade do ambiente. In: XII Congresso Brasileiro de Viticultura e Enologia - Anais. Bento Gonçalves, 92 p., 2008.

Vitti, A.; Sebastiani, R.E.G.; Vicentini, C.A.; Bote, M. Perspectivas da fruticultura brasileira exportadora frente aos novos investimentos. In: XLVI Congresso da Sociedade Brasileira de Economia e Sociologia Rural (SOBER); Rio Branco - AC, 2008.

License information: This is an open-access article distributed under the terms of the Creative Commons Attribution License (type CC-BY), which permits unrestricted use, distribution and reproduction in any medium, provided the original article is properly cited. 